\title{
Development of a Microwave Resonator and Effects of Electric and Magnetic Fields on Cultured Cancer Cells
}

\author{
MAMIKO ASANO ${ }^{1,2 *}$, JUN-ICHI SUGIYAMA ${ }^{3}, \mathrm{KENICHI} \mathrm{KAWANO}^{4}$, SHIROH FUTAKI ${ }^{4}$ \\ ${ }^{1}$ Research Institute for Sustainable Humanosphere, Kyoto University, Uji 611-0011, Japan \\ ${ }^{2}$ Faculty of Pharmaceutical Sciences, Osaka University of Pharmaceutical Sciences, 4-20-1 Nasahara, Takatsuki, \\ Osaka 569-1094, Japan \\ ${ }^{3}$ National Institute of Advanced Industrial Science and Technology (AIST), Tsukuba Central 5, 1-1-1 Higashi, \\ Tsukuba, Ibaraki 305-8565, Japan \\ ${ }^{4}$ Institute for Chemical Research, Kyoto University, Uji, Kyoto 611-0011, Japan
}

\begin{abstract}
Microwaves can both electrically and magnetically permeate a target substance; however, the permeation can also be affected by the components and composition of the target substance. These factors complicate our understanding of how microwave irradiation affects living cells, thus limiting the therapeutic application of microwave irradiation, such as in cancer treatment. We previously investigated how microwave irradiation promotes cell death in cancer cells and now aim to evaluate the potential mechanisms underlying microwave-induced cell death. In this study, we investigated the mechanism underlying cell death in response to microwave heating. First, a microwave resonator that could precisely control microwave energy and separately generate an electric field and a magnetic field in a dish was developed. This system was employed to confirm whether it is the electric or the magnetic field in the microwave that affects the death of the human pancreatic carcinoma cell line, Panc-1. Cells were killed at the position where the electric field strength was at a maximum, suggesting that dielectric loss might affect cell death. Meanwhile, cell death was not induced at the position where the magnetic field strength was at a maximum, suggesting that the magnetic field might not affect cell death.
\end{abstract}

Key Words: Panc-1, microwave heating, electric field, magnetic field, cell death

\section{Introduction}

Microwaves - a type of electromagnetic wave — can efficiently heat a substance by creating vibrations from electric and magnetic fields. Microwaves heat a substance through three different mechanisms, specifically dielectric loss, conduction loss, and magnetic loss ${ }^{1-2}$. When an electric field is applied to a substance, positive and negative charges in the substance move along the direction of the electric field. When a molecule is charged, a cation moves toward the negative electrode, whereas an anion moves toward the positive electrode. At this time, the amount of heat generated depends on the value of conductivity, which is an intrinsic feature of the substance, and depends on the electric field energy applied. Even if the molecule

Received 20 August, 2020, Accepted 2 February, 2021: *Correspondence author: Tel, +81-774-38-3346 or +81-72-690-1000;

e-mail, asanom_oups@yahoo.co.jp

doi: 10.3191 /thermalmed.37.15

2021 Japanese Society for Thermal Medicine 
does not have an electric charge, it responds to the electric field by changing the direction of polarity, provided the molecule has an electric dipole. The attenuation of energy based on the electric conductivity is called conductive loss, and attenuation based on electric permittivity is called dielectric loss. When heating by electric field irradiation, whether a substance is susceptible to dielectric loss or conduction loss depends on the frequency. Both of these are electric losses and depend on the electric permittivity or conductivity of the material and the amount of applied electric field energy.

Unlike electric field irradiation, when a magnetic field is applied, magnetic materials and the current respond. When a microwave is applied to magnetic materials such as iron nanoparticles, a response based on the orientation of the magnetic dipoles occurs. Attenuation of microwave energy in this case is called magnetic loss. Magnetic loss depends on the magnetic permeability of the material and the amount of applied magnetic field energy.

As described, the identity of the heating methods used depends on the electric conductivity, electric permittivity, and magnetic permeability of the substance. Therefore, analyzing the mechanism when complex compounds are heated by microwave irradiation at the same time is a challenging task. For example, cells contain many compounds, and it is extremely difficult to evaluate the heating mechanism for each molecule in cells. In contrast, cells are mainly composed of water-soluble proteins, sugars, lipids, and electrolytes, and thus can be regarded as a single aggregate for microwave heating. By analyzing the dielectric properties of cells as one substance, we can easily understand the microwave heating mechanism of whole cells.

We investigated the effects of microwave irradiation on cancer cells and previously reported that several cancer cell lines were killed by microwave irradiation under normothermic conditions ${ }^{3-5)}$. We measured the dielectric constants of cancer cells, cell cultures, and their media and found no significant differences among the dielectric constants ${ }^{3}$. The cell death type in the human promyelocytic leukemia cell line HL-60 was found to be caspase-independent apoptosis, which was not related to the heat stress responses ${ }^{4}$. To date, there are no studies that have focused on microwave irradiation-induced cell death while considering the mechanism of microwave heating, and in general, analysis has been performed only from the viewpoint of an increase in cellular temperature. However, microwave heating is a unique heating mechanism that involves molecular vibrations described previously herein. Therefore, we infer that not only cellular temperature increases but also microwave irradiation itself might directly affect the cell functional changes involved in cell death. In this study, we investigated whether microwave electric or magnetic fields affect cell viability. First, we developed a microwave irradiation system that could separately irradiate using the electric field or magnetic field in a dish. Then, we added cells from the human pancreatic carcinoma cell line Panc-1 to the system.

\section{Materials and Methods}

\section{Cancer cell line and microwave irradiation method}

We used human pancreatic cancer-derived Panc-1 cells (transferred from RIKEN BRC, Tsukuba, Japan). The cells were seeded in a 35-mm cell culture dish (3000-035, AGC TECHNO GLASS, Yoshida, Japan) at a density of $1 \times 10^{5}$ cells $/ \mathrm{mL}$ and irradiated with microwaves for 2 hours using the developed irradiation system. 


\section{Hoechst 33342 staining}

During microwave irradiation, the inside of the resonator was cooled using a Peltier cooler, and the central temperature inside the dish was maintained at $40{ }^{\circ} \mathrm{C}$. The central temperature was adjusted by calculating the difference between the temperature of the radiation thermometer and that of a fiber thermometer in advance and was maintained by measuring the temperature using the radiation thermometer during the experiment. After irradiation with microwaves, cells were cultured in a $\mathrm{CO}_{2}$ incubator for 24 hours and were fixed with $4 \%$ PFA for 30 minutes. After washing with PBS, cells were permeabilized using $0.2 \%$ triton for 5 minutes. After washing with PBS, the cells were stained using Hoechst 33342 (final concentration, $5 \mu \mathrm{g} / \mathrm{mL}$; Nacalai Tesque, Kyoto, Japan) for 5 minutes. After washing with PBS, the number of cells was calculated using IX70 (Olympus, Tokyo, Japan; excitation wavelength, 330-385 nm).

\section{Measurement of mitochondrial membrane potential}

After irradiation with microwaves, cells were incubated in a $\mathrm{CO}_{2}$ incubator for 24 hours. Cells were stained with JC-1 (final concentration, $2 \mu \mathrm{M}$; Nacalai Tesque, Kyoto, Japan) for 30 minutes. After washing with PBS, cells were observed using IX70 (Olympus, Tokyo, Japan; excitation wavelength, 460-495 nm).

\section{Results}

\section{Dielectric constant in the medium}

A Nyquist diagram shows the permittivity and conductivity at the measurement frequency as complex numbers and can be created by measuring the propagation speed and loss speed of the electric field. Dielectric loss is the response of the electric dipole and saturates in infinite time. Therefore, it has a coefficient that defines relaxation time. Conduction loss is a single charge response. At this time, the electric charge moves regardless of time, and current is generated. In the Nyquist diagram, when the frequency is swept, the dielectric loss draws a semicircle with the relaxation frequency at the apex, while the conductive loss draws a straight line. Further, the Nyquist diagram shows the degree of loss of the propagating electromagnetic waves of a substance. The degree of loss is indicated by $\tan \delta$, which is the slope of the straight line connecting the origin and its measurement point. In this study, it is considered that the loss of electromagnetic waves is the conversion of electromagnetic wave energy into thermal energy at the irradiation target.

Therefore, we analyzed whether the dielectric loss or the conductive loss is mainly affected in our microwave heating method by evaluating whether the irradiation frequency ( $2.45 \mathrm{GHz}$ this time) is plotted in a semicircle or a straight line in the Nyquist diagram. First, we confirmed the dielectric constant in the medium with a network analyzer using aVector Network Analyzer (ZVB14/17, Rohde \& Schwarz, Munich, Germany) with a semi rigid cable assembly (PT292M2024486 Pigtail, Kawashima Manufacturing, Kawasaki, Japan). Fig. 1 shows a Nyquist diagram at a frequency of $400 \mathrm{MHz}$ to $10 \mathrm{GHz}$ from $30{ }^{\circ} \mathrm{C}$ to $50{ }^{\circ} \mathrm{C}$. In general, this figure shows that the dielectric loss is dominant in the frequency region approximated by a semicircle and that conductive loss is dominant in the frequency region approximated by a straight line. The behavior at $2.45 \mathrm{GHz}$ is plotted on a semicircle rather than on a straight line, which explains why this illuminated object exhibits predominantly dielectric properties for $2.45 \mathrm{GHz}$ microwaves. In addition, tan $\delta$, which is $\varepsilon_{\mathrm{r}}^{\prime \prime} /$ $\varepsilon_{r}^{\prime}$, indicates the degree of microwave loss. Because $\tan \delta$ decreases with increasing temperature in the range of $30{ }^{\circ} \mathrm{C}$ to $50{ }^{\circ} \mathrm{C}$, the contribution of microwave heating with increasing temperature has been shown to 
decrease, which is similar to the phenomenon where irradiation at $2.45 \mathrm{GHz}$ for water containing dilute ions is heated by dielectric losses.
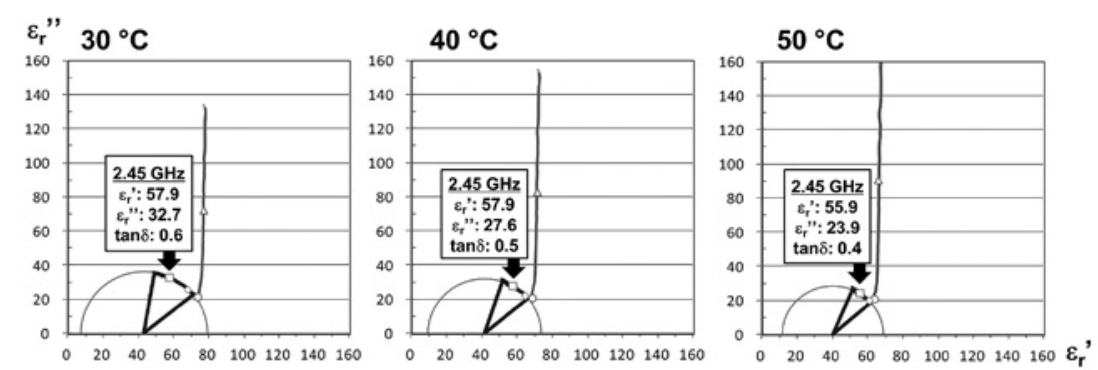

Fig. 1. The Nyquist diagram of the medium at a frequency of $400 \mathrm{MHz}$ to $10 \mathrm{GHz}$ from $30{ }^{\circ} \mathrm{C}$ to $50{ }^{\circ} \mathrm{C}$.

\section{Development of the microwave irradiation system}

Fig. 2A shows our microwave irradiation system comprising a microwave resonator, a $2.45 \mathrm{GHz}$ semiconductor oscillator (AMIL-HMW50-01S1, irradiation power 0-50 W, AMIL, Tokyo, Japan), and applicators. We adopted a WRJ-22 $(109.2 \times 54.6 \mathrm{~mm})$ type waveguide connected to a WRJ-22/N-type coaxal waveguide converter; the end of the waveguide can be adjusted by a moving short. The temperature inside the waveguide can be adjusted using a Peltier cooler on the top of the waveguide. The waveguide is covered with Teflon (polytetrafluoroethylene, PTFE) to maintain a constant temperature inside the waveguide. We could place a dish at the center of waveguide; the sample temperature was measured using a radiation thermometer (TMHX-CNE0500-0035E1.6, Japan Sensor, Tokyo, Japan) in the center. In addition, the temperature of the dish could be controlled to raise to the target temperature of the radiation thermometer using a temperature controller (E5CCQQ0ASM-000, OMRON, Kyoto, Japan) connected to the Peltier. Furthermore, the output of the incident power and reflected power can be monitored using a digital multimeter (PC7000, Sanwa Electric Instrument, Tokyo, Japan), and the temperature can be monitored using a data logger (PicoLog, Pico Technology, St Neots, UK).

The length of the waveguide was adjusted by moving the sliding short circuit so that the inside of the device resonated at an oscillation frequency of $2.45 \mathrm{GHz}$. Specifically, the $\mathrm{S}$ parameter $\left(\mathrm{S}_{11}\right)$ was measured using a network analyzer (N5242A, Agilent Technologies, Santa Clara, USA). As a sample, we used $2.5 \mathrm{~mL}$ of RPMI 1640 which has the same dielectric properties as the cell culture

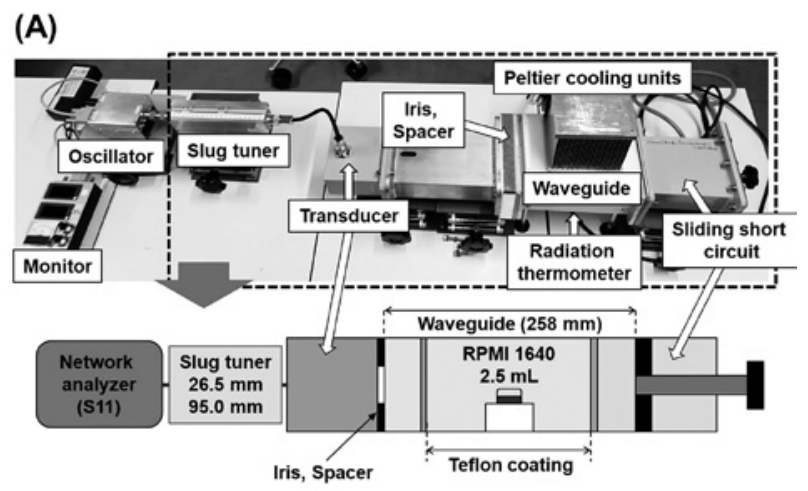

(B)

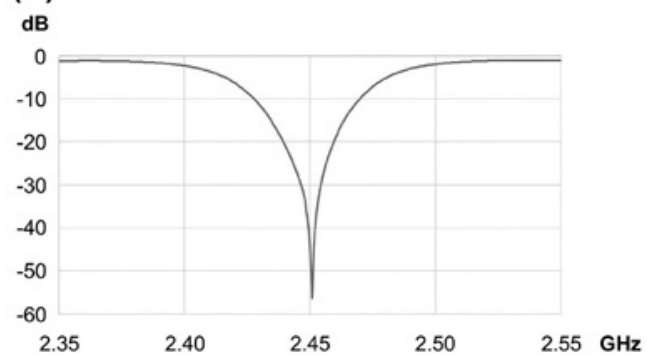

Fig. 2. Overview of the proposed microwave irradiation system. Our microwave irradiation system consists of a microwave resonator, a $2.45 \mathrm{GHz}$ semiconductor oscillator, and several applicators (A). The waveguide length was adjusted by maximizing the resonance frequency at $2.45 \mathrm{GHz}$. Based on the $\mathrm{S}$ parameter $\left(\mathrm{S}_{11}\right)$ measurement, the resonant frequency at $2.45 \mathrm{GHz}$ was maximized when the resonator length was $258.0 \mathrm{~mm}(\mathbf{B})$. 
medium ${ }^{3)}$. The RPMI 1640 was placed in a $35-\mathrm{mm}$ dish, and the length of the resonator was optimally adjusted by the $\mathrm{S}_{11}$ measurement. The device resonated at $2.45 \mathrm{GHz}$ when the length was $258.0 \mathrm{~mm}$. When the permittivity changed because of temperature changes, the resonance frequency shifted; however, because the change in permittivity due to the temperature increase was small for this irradiation target, we used it without changing the length of the resonator during irradiation (Fig. 2B).

Next, we conducted simulation analysis of the electromagnetic field strength by the FDTD method (finitedifference time-domain method) using CST Studio Suite 2019 (Dassault Systèmes K.K., Paris, France) (Fig. 3). In the analysis, we used the value of the dielectric constant of the medium for Panc-1 cells (10\% fatal bovine serum (GE healthcare, Chicago, USA), GlutaMAX (Thermo Fisher Scientific, Waltham, USA), and antibiotic reagents (Penicillin-Streptomycin Mixed Solution, Nacalai Tesque, Kyoto, Japan) in RPMI 1640 (Nacalai Tesque, Kyoto, Japan) as proposed by Asano et al. The physical property values used for the simulation analysis are as follows:

Teflon: $\varepsilon_{\mathrm{r}}^{\prime}=2.1 ; \tan \delta=0.0$ (Teflon (loss-free) model; the values are registered in the analysis software) Dish (made of polystyrene): $\varepsilon_{\mathrm{r}}^{\prime}=2.6 ; \tan \delta=0.00040(3 \mathrm{GHz}$ ) (quoted from Ref. 6) Cell culture medium: $\varepsilon_{\mathrm{r}}^{\prime}=75$; $\tan \delta=0.29$ (quoted from Ref. 3)

The mesh size in the simulation analysis divides the inside of the waveguide, which is the calculation

(A)
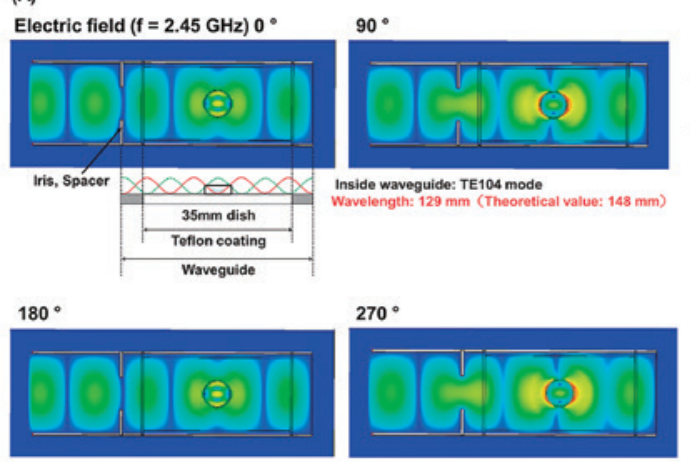

$270^{\circ}$
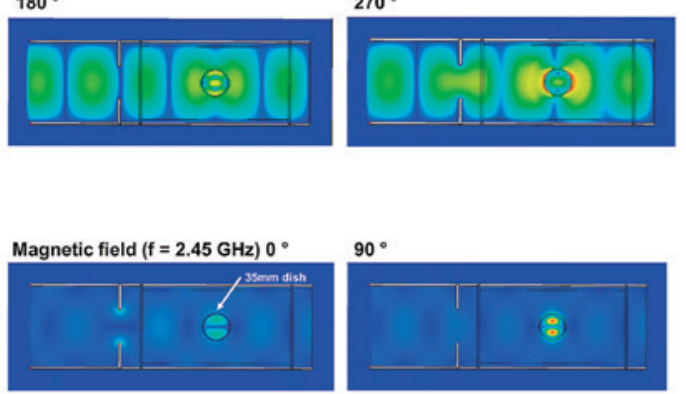

$180^{\circ}$

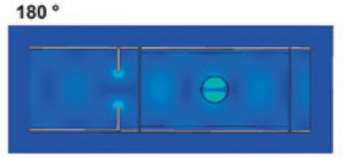

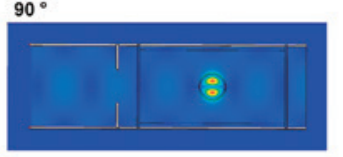

$270^{\circ}$

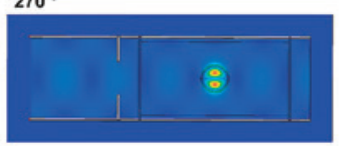

(B)
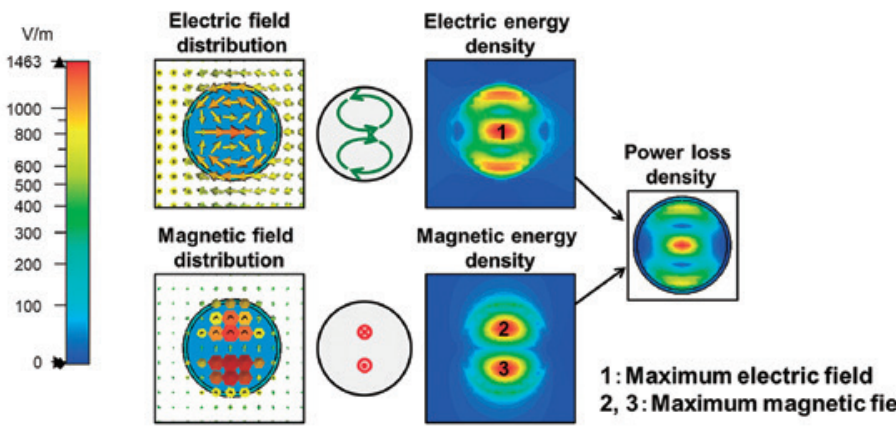

(C)

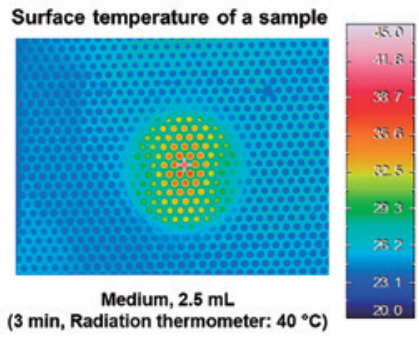

Fig. 3. Simulation of electric and magnetic field energy and temperature distribution in our microwave irradiation system. Electromagnetic simulations were performed by employing a finite-difference time domain (FDTD) method with CST STUDIO SUITE 2018 (AET, INC, Kawasaki, Japan), which transmitted a continuous microwave at 2.45 GHz (A). The enlarged view of the distribution and energy density in the electric and magnetic field around a 35-mm dish with medium (B). Temperature distribution in a $35-\mathrm{mm}$ dish with $2.5 \mathrm{~mL}$ of medium after 3 minutes following microwave irradiation at $40{ }^{\circ} \mathrm{C}$ using a radiation thermometer $(\mathbf{C})$. 
space, into 200,000 to 250,000 hexahedral cells. This split was conducted automatically by the software and was not evenly spaced. For example, a part of the cell culture medium was divided into approximately 50 parts of $35-\mathrm{mm}$ in a dish to maintain the smoothness of the curved part. In addition, a perfect electric conductor (PEC) was set at the boundary with the outside world. The electromagnetic wave input port was set to impedance match in the assumed $\mathrm{TE}_{10}$ mode.

\section{Simulation analysis of the electromagnetic field strength}

The simulation results show that there was a $\mathrm{TE}_{104}$ mode in which four electric field maxima occurred along the progressive direction of the microwave inside the rectangular resonator. This is because the Teflon support used to fix the dish was large, and the wavelength was shortened inside it. In addition, the irradiation target in the dish was close to the composition of water, resulting in a larger wavelength reduction. Therefore, the electromagnetic field distribution exhibited a shape similar to that of the $\mathrm{TE}_{120}$ mode when the dish was a cylinder. The use of this device for irradiation allows for the simultaneous performance of an experiment in the region where the electric field strength and magnetic field strength are maximum, namely at the center of the dish (1 in Fig. 3B) and in the region beside it ( 2 and 3 in Fig. 3B), respectively. By using this system, we investigated whether electric or magnetic fields affect cell death.

To validate the results of the electromagnetic field simulation analysis, the temperature distribution of the dish was measured. In the case of dielectric heating, the temperature increases at the location where the electric field strength is high. Therefore, we can estimate the strength of the electric field by measuring the temperature distribution. In this study, we observed the changes in the surface temperature distribution of the medium for Panc-1 cells in the dish using a thermo camera (H2630, Nippon Avionics, Yokohama, Japan, Fig. 3C). The resolution of the thermo camera was $640(\mathrm{H}) \times 480(\mathrm{~V})$ dots, and the material of the dish was polystyrene. Normally, it is impossible to measure the temperature distribution from the outside using a thermo camera because the resonator is covered with metal to prevent the leakage of microwaves to the outside. In this experiment, we measured the emitted light of the thermo camera by making an upper part of the resonator a mesh. Then, $2.5 \mathrm{~mL}$ of the medium was added to a $35-\mathrm{mm}$ dish without a lid. After 30 seconds of microwave irradiation, we observed that the temperature distribution exhibited the same shape as that of the simulation results of the electric field distribution. The shape of the temperature distribution was maintained for more than 1 hour. Moreover, the temperature at the position of 2 and 3 in Fig. 3B was several degrees lower than that of the center of the dish (1 in Fig. 3B) during microwave irradiation.

Next, we measured the temperature inside the medium using a fiber thermometer. In this experiment, we placed the Peltier cooler on top of the mesh of the resonator. By using the Peltier cooler, we could prevent excessive temperature increases induced by microwave irradiation and keep the temperature constant because the cooling air can be provided from the outside. The temperature of the center of the dish (1 in Fig. 3B) was $40{ }^{\circ} \mathrm{C}$ when the mean value of the output (output of incident power - output of reflected power) was $1.1 \mathrm{~W}$. We irradiated with microwave for 2 hours by adjusting manually in order not to exceed the maximum temperature, which was $40 \pm 1{ }^{\circ} \mathrm{C}$. The initial temperature was $21.9^{\circ} \mathrm{C}$, and the irradiation time was 2 hours. In this case, it is supposed that the medium becomes hard to heat by microwave irradiation as the temperature rises because the tan $\delta$ values of the medium decreased according to the increase in temperature (Fig. 1). However, we inferred that this phenomenon can be ignored because the temperature difference in a dish was not large. 


\section{Effects of the electric field or magnetic field on cell death}

Finally, we investigated whether electric field or magnetic field affect cell death. The number of Panc-1 cells in the medium was decreased significantly by microwave irradiation at the center of the dish (1 in Fig. 3B) where the electric field was at a maximum (Fig. 4A). The rate of decrease was $32.5 \%$ when compared with the number of cells without microwave irradiation, indicating that $67.5 \%$ of the cells were still alive despite microwave irradiation. At locations 2 and 3 in Fig. 3B where the magnetic field strength was at a maximum, no significant difference was observed in the number of cells in response to microwave irradiation.

Furthermore, the mitochondrial membrane potential of the Panc- 1 cells at the center of the dish (1 in Fig. 3B) was confirmed by JC-1 staining. JC-1 enters mitochondria selectively and its fluorescence changes reversibly from green to red as the membrane potential increases and decreases. We confirmed green fluorescence in several cells in the center of the dish (1 in Fig. 3B), indicating that the mitochondrial membrane

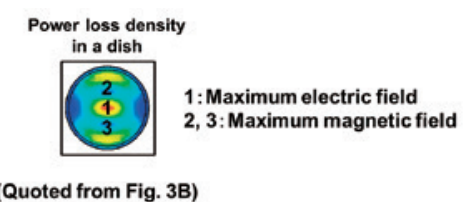

(Quoted from Fig. 3B)

(A)

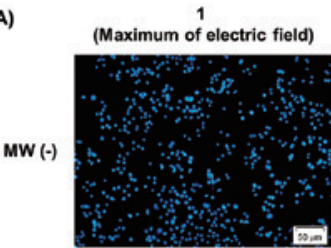

(Maximum of ${ }^{2}$
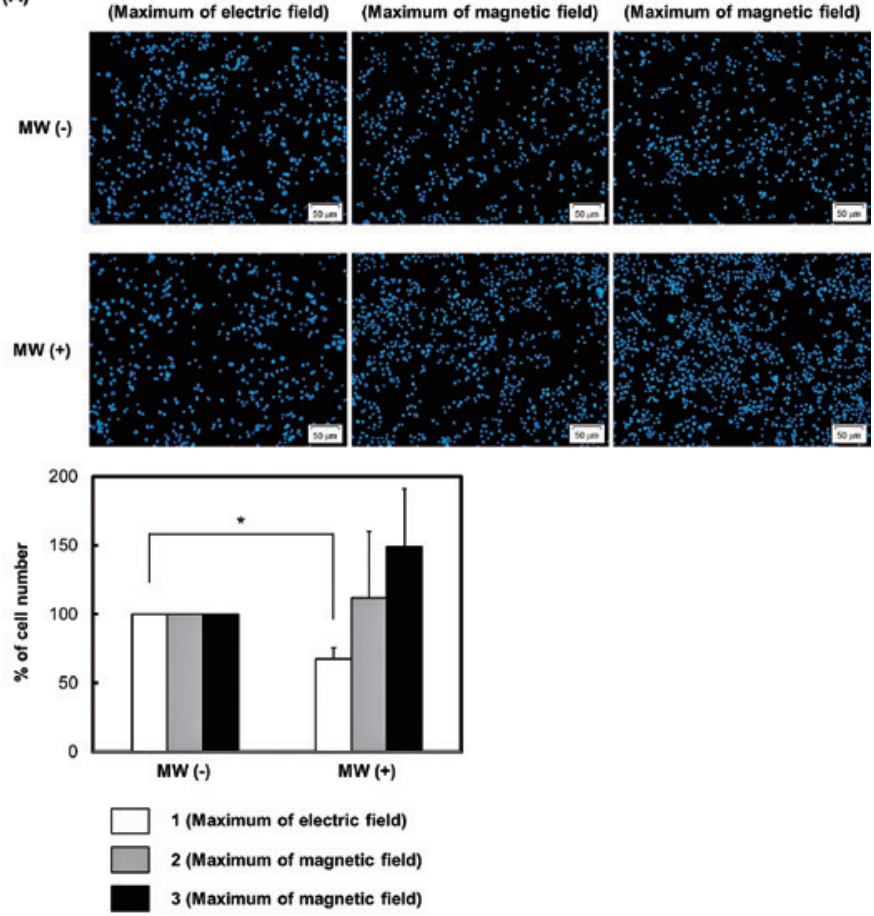

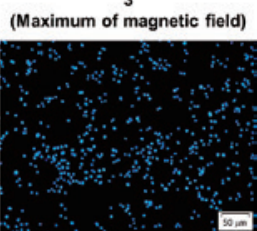

(B)

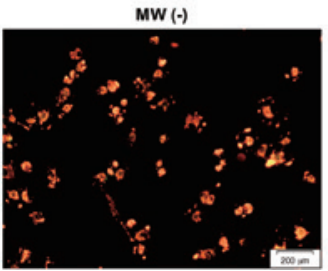

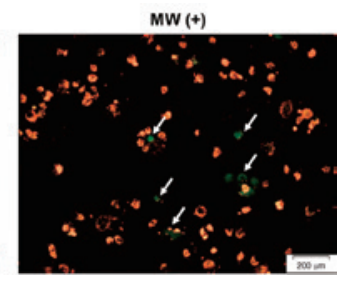

Fig. 4. Effects of electric and magnetic fields on Panc-1 cell death.

Fluorescence microscopy-based images of Panc-1 cells exposed to microwave irradiation at positions 1, 2, and 3 in Fig. 3B (A). The maximum strength of the electric field was at location 1 in the dish, and the maximum strength of the magnetic field was at locations 2 and 3. Microwave irradiation (described as 'MW') was applied for 2 hours and the temperature of the cultured cells was maintained at $40{ }^{\circ} \mathrm{C}$. After the cessation of irradiation, cells were moved to a $\mathrm{CO}_{2}$ incubator and incubated for 24 hours. Rates are shown relative to the number without microwave irradiation (MW (-), f values were defined as "100". Mitochondrial membrane potential was determined for Panc- 1 cells at the center of the dish (1 in Fig. 3B) using the JC-1 assay (B). Data are expressed as the mean \pm SD of four independent experiments. Asterisk indicates a significant difference from the cell number without microwave irradiation: $* \mathrm{P}<0.05$. 
potential was lost in some cells (Fig. 4B). Thus, cells were killed via mitochondrial damage via local heating due to dielectric loss.

\section{Discussions}

In conclusion, cells were killed by the electric field, not by the magnetic field. We inferred that one of the reasons underlying cell death might be the increase in cell temperature via dielectric loss. Because it is common knowledge that cell death is induced when the temperature of cells is increased by microwave irradiation, this phenomenon is used for cancer therapies such as microwave coagulation therapy and hyperthermia. It is considered that cancer cells subjected to therapies are heated by dielectric loss because the microwave frequency that is used is $2.45 \mathrm{GHz}$. Moreover, it has been reported that Panc-1 cells are killed by mild hyperthermia, which kills cancer cells at temperatures below $42.5^{\circ} \mathrm{C}^{7}$. In our previous studies, we found that Panc-1 cells were killed by incubation at $42.5^{\circ} \mathrm{C}^{3}$. . However, we must also discuss whether the non-thermal effects of the electric field could induce cell death. We previously found that Panc-1 cells were killed by microwave irradiation in normothermic conditions ${ }^{3}$. If cell death is induced by the non-thermal effect, it is thought that the reason for this might be the increase in the electric field potential of cells mediated by the application of the electric field. However, we cannot confirm the existence of this phenomenon by this study only, and thus, we need further analysis to address this question. For example, we must develop a system in which the temperature inside cells can be monitored in real time during microwave irradiation. Then, we would investigate whether cell death is induced by application of the electric field when the temperature of cells is not increased.

Moreover, cell death was not induced at the position where the magnetic field was maximum, suggesting that the magnetic field might not affect cell death. It has been reported that there are magnetic substances such as ferritin in cells ${ }^{8}$. However, in this experiment, we inferred that these substances were not heated by the magnetic field at the temperature at which cell death was induced.

We also found that mitochondrial damage in Panc-1 cells is associated with the irradiation of the electric field. There are no reports showing that mild hyperthermia induces mitochondrial damage in Panc-1 cells. However, it has been reported that the mitochondrial membrane potential of other cells disappears after mild hyperthermia treatment ${ }^{9}$. It is well-known that mitochondrial damage is one of the most important factors causing apoptosis and programmed necrosis ${ }^{4,10-11)}$. Therefore, it is suggested that this mitochondrial damage might be related to cell death induced by microwave irradiation. In the future, we will investigate which cell death pathways are associated with mitochondrial damage. To investigate whether cell death is related to apoptosis or not, we have to investigate the activation of caspase 3/7 and DNA fragmentation. If cell death is related to programmed necrosis, we have to investigate the activation of caspase 8 and analyze using an inhibitor of programmed necrosis.

\section{Acknowledgments}

We gratefully acknowledge the skillful technical assistance of Amil Co., Ltd. and Kumagai RF applications Co., Ltd. for the development of the irradiation system. We specially appreciate Dr. S. Kojima and Prof. N. Shinohara (Research Institute for Sustainable Humanosphere, Kyoto University) for the technical advice on simulation analysis. Further, we would like to specially thank Prof. R. Uda (National Institute of Technology, 
Nara College) and Dr. T. Imai (Research Institute for Sustainable Humanosphere, Kyoto University) for their valuable advice. Parts of this study were funded by Japan Society for the Promotion of Science (JSPS) KAKENHI (Grant Number 15K21516 and 18K12123), 11 th Shiseido Female Researcher Science Grant, the Research Foundation for Pharmaceutical Sciences, and the Analysis and Development System for Advanced Materials (ADAM) at the Research Institute for Sustainable Humanosphere, Kyoto University.

\section{Author Contributions}

Conceived and designed the experiments: M.A. and J.S. Performed experiments: J.S. and M.A. (electromagnetic analysis) and M.A. (cytological analysis). Contributed reagents, materials, and analysis tools: M.A., J.S., K.K., and S.F. Analyzed the data and discussed the results: J.S. and M.A. (electromagnetic considerations) and M.A., K.K., and S.F. (cytological considerations). Wrote the paper: M.A. and J.S.

\section{Conflict of interest}

The authors declare no conflicts of interest.

\section{References}

1) Sugiyama J.: Electromagnetic relationship between microwaves and flow reactor systems. Chem Rec, 19: 146-156, 2018.

2) Stuerga D., Delmotte M.: Fundamentals of microwave-matter interactions. "Microwaves in Organic Synthesis." Ed. A. Loupy, Wiley-VCH, pp.1-18, 2002.

3) Asano M., Sakaguchi M., Tanaka S., Kashimura K., Mitani T., Kawase M., Matsumura H., Yamaguchi T., Fujita Y., Tabuse K.: Effects of normothermic conditioned microwave irradiation on cultured cells using an irradiation system with semiconductor oscillator and thermo-regulatory applicator. Sci Rep, 7: 41244, 2017.

4) Asano M., Tanaka S., Sakaguchi M., Matsumura H., Yamaguchi T., Fujita Y., Tabuse K.: Normothermic microwave irradiation induces death of HL-60 cells through heat-independent apoptosis. Sci Rep, 7: 11406, 2017.

5) Asano M., Tanaka S., Sakaguchi M.: Effects of normothermic microwave irradiation on CD44+/CD24- in breast cancer MDA-MB-231 and MCF-7 cell lines. Biosci Biotech Biochem, 84: 103-110, 2020.

6) https://permittivity.jp/cgi-bin/permittivity/chart.cgi?material_id $=420 \&$ measurement_id $=0 \&$ reference_id $=1 \&$ xaxis $=$ freq uency\&unit $=[\mathrm{Hz}] \&$ unit_a $=\mathrm{mhz} \& \mathrm{fl}=0 \&$ concent $=1$

7) Krzykawska-Serda M., Agha M.S., Ho J.C., Ware M.J., Law J.J., Newton J.M., Nguyen L., Curley S.A., Corr S.J.: Chemotherapy and radiofrequency-induced mild hyperthermia combined treatment of orthotopic pancreatic ductal adenocarcinoma xenografts. Transl Oncol, 11: 664-671, 2018.

8) Stanley S.A., Sauer J., Kane R.S., Dordick J.S., Friedman J.M.: Remote regulation of glucose homeostasis in mice using genetically encoded nanoparticles. Nat Med, 21: 92-98, 2015.

9) Wang Z., Cai F., Xiaoyu C.X., Luo M., Hu L., Lu Y.: The role of mitochondria-derived reactive oxygen species in hyperthermia-induced platelet apoptosis. PLoS One, 8: e75044, 2013.

10) Galluzzi L., Vitale I., Abrams J.M., Alnemri E.S., Baehrecke E.H., Blagosklonny M.V., Dawson T.M., Dawson V.L., El-Deiry W.S., Fulda S., Gottlieb E., Green D.R., Hengartner M.O., Kepp O., Knight R.A., Kumar S., Lipton S.A., Lu X., Madeo F., Malorni W., Mehlen P., Nuñez G., Peter M.E., Piacentini M., Rubinsztein D.C., Shi Y., Simon H-U., Vandenabeele P., White E., Yuan J., Zhivotovsky B., Melino G., Kroemer G.: Molecular definitions of cell death subroutines: recommendations of the Nomenclature Committee on Cell Death 2012. Cell Death Differ, 19: 107-120, 2012

11) Ouyang L., Shi Z., Zhao S., Wang F.T., Zhou T.T., Liu B., Bao J.K.: Programmed cell death pathways in cancer: a review of apoptosis, autophagy and programmed necrosis. Cell Prolif, 45: 487-498, 2012. 


\title{
Abstract in Japanese
}

\section{共振器型マイクロ波照射装置の開発と培養癌細胞に 対するマイクロ波の電場と磁場の影響}

\author{
1京都大学 生存圈研究所 \\ 2 大阪薬科大学薬学部 \\ 3産業技術総合研究所 \\ 4 京都大学 化学研究所
}

浅野麻実子 ${ }^{1,2} \cdot$ 杉 山順 - ${ }^{3} \cdot$ 河 野 健 - $^{4} \cdot$ 二 木史 朗 ${ }^{4}$

要旨: マイクロ波は, 電場と磁場によって物質を加熱する。この時, 物質へのマイクロ波の吸収 や加熱の度合いは，その成分や組成に影響される，細胞は，多種類の物質が様々な組成で混合した集合 体であることから，マイクロ波加熱のメカニズムを細胞内で理解することは極めて難しい. したがって， 加熱機構を考慮した上で, マイクロ波照射が細胞に与える影響を解析することは重要である. 我々はこ れまでに, マイクロ波照射が複数の培養癌細胞の細胞死を誘導することを明らかにし, その細胞死メカ ニズムを解析した。本研究では, マイクロ波の電場と磁場のどちらが培養癌細胞の死滅に強く影響を及 ぼすかを調べた。まず初めに，共振器型マイクロ波照射装置を開発した。本装置は，1つのシャーレ内 に照射される電場及び磁場成分の割合が異なっている。次に本装置を用いて, ヒト膵臓癌細胞株 Panc-1 がマイクロ波の電場及び磁場成分のどちらの影響で死滅するのかを確認した。 その結果, 電界強度が最 大の位置で細胞死が誘導されたことから, 誘電損失が細胞死に影響を与えると推測した。 一方, 磁場強 度が最大の位置では細胞死は誘導されず, 磁場は細胞死に影響を与えなかった。

Thermal Med, 37[1]: 15-24, 2021. 